\title{
Gonadotrophin and steroid concentrations in bovine follicular fluid and their relationship to follicle size
}

\author{
K. M. Henderson, A. S. McNeilly* and I. A. Swanston* \\ Department of Biochemistry, University of Western A ustralia, Nedlands, Western Australia \\ 6009 and ${ }^{*}$ M.R.C. Centre for Reproductive Biology, 37 Chalmers Street, Edinburgh EH3 9EW, \\ U.K.
}

\begin{abstract}
Summary. The concentrations of LH, FSH and prolactin, and oestradiol-17 $\beta$, androstenedione, testosterone and progesterone were measured in follicular fluid from small, medium and large bovine follicles. As follicle size increased, there was a significant increase in median fluid concentrations of prolactin (2-fold) and oestradiol-17 $\beta$ (14-fold) and a significant decrease in concentrations of $\mathrm{LH}$ (to $73 \%$ ), androstenedione (to $30 \%$ ) and testosterone (to $10 \%$ ). There was no relationship between follicle size and fluid concentrations of FSH or progesterone, or between fluid concentrations of FSH and the relative concentrations of androgen and oestradiol-17 $\beta$. As follicle size increased there was a significant increase in the proportion of follicles in which follicular fluid concentrations of oestradiol-17 $\beta$ exceeded those of androgen. There was a significant relationship between follicular fluid concentrations of prolactin and progesterone; as fluid prolactin concentrations increased, the maximum concentration of progesterone observed decreased.
\end{abstract}

\section{Introduction}

While the concentrations of ovarian steroids and gonadotrophins present in blood throughout the oestrous cycle of the cow have been well documented (Kanchev, Dobson, Ward \& Fitzpatrick, 1976; Schams, Schallenberger, Hoffmann \& Karg, 1977; Ireland, Coulson \& Murphree, 1979; Rahe, Owens, Fleeger, Newton \& Harms, 1980), no information is available regarding the concentrations of gonadotrophins present in follicular fluid or their relationship to steroids present there. Studies in other species indicate that the relative follicular fluid concentrations of steroids and gonadotrophins vary widely between follicles, and that the intrafollicular environment of steroids and gonadotrophins may be an important regulator of follicular development (Moor, Hay, Dott \& Cran, 1978; McNatty, 1978; McNatty, Gibb, Dobson, Thurley \& Findlay, 1981). The purpose of this study was to determine what interrelationships existed between steroids and gonadotrophins present in bovine follicular fluid.

\section{Materials and Methods}

\section{Collection of follicular fluid}

Ovaries were obtained from 53 adult, non-pregnant cows within $1 \mathrm{~h}$ of their slaughter during 16 separate visits to a local Edinburgh abattoir between the months of October and February. The ovaries were transported to the laboratory in ice-chilled Eagle's Minimum Essential Medium 
(Modified) with Earle's Salts (Flow Laboratories, Irvine, Scotland). Follicular fluid from all antral follicles protruding at the surface of the ovary was aspirated individually using a syringe (1 or $2 \mathrm{ml}$ ) and needle (20-26 gauge). Fluid from follicles containing $\leqslant 0.1 \mathrm{ml}$ fluid was pooled for follicles from the same ovary or each pair of ovaries. All other fluids were analysed separately. Follicles containing $<0.3 \mathrm{ml}$ fluid were classified as small. This group consisted of 31 separate pools of follicular fluid from follicles containing $\leqslant 0.1 \mathrm{ml}$ fluid and 15 fluids from individual follicles with $>0.1 \mathrm{ml}$ to $<0.3 \mathrm{ml}$ fluid. Follicles containing $\geqslant 0.3 \mathrm{ml}$ to $<0.8 \mathrm{ml}$ fluid and $\geqslant 0.8$ $\mathrm{ml}$ fluid were classified as medium $(n=35)$ and large $(n=37)$ respectively. The median volume collected from large follicles was $1.0 \mathrm{ml}$ and the greatest volume was $2.2 \mathrm{ml}$. All fluids were frozen immediately after aspiration until assayed for gonadotrophin and steroids by radioimmunoassay. The time between collecting the ovaries and freezing the aspirated follicular fluid was $<75 \mathrm{~min}$. Regression analysis on 23 individual follicles containing $0.05-1.3 \mathrm{ml}$ follicular fluid indicated that follicular volume $(\mathrm{V} ; \mu \mathrm{l})$ could be related to follicular diameter $(\mathrm{D} ; \mathrm{mm})$ by the equation $\mathrm{V}=0.3 \times \mathrm{D}^{3}$.

\section{Radioimmunoassays}

Gonadotrophins. The concentrations of luteinizing hormone (LH), follicle-stimulating hormone (FSH) and prolactin in follicular fluid were measured using the assays described previously by Scaramuzzi, Caldwell \& Moor (1970), McNeilly, McNeilly, Walton \& Cunningham (1976) and McNeilly \& Andrews (1974) respectively. While these assays were originally developed to measure ovine gonadotrophins, the LH and FSH assays have been validated for use in the cow (Bass, McNeilly \& Moreton, 1979). The prolactin assay was specific for bovine prolactin (NIH-P-B 12), showing negligible cross-reaction $(<0.5 \% \mathrm{w} / \mathrm{w}$ at $50 \% \mathrm{~B} / \mathrm{Bo})$ with other bovine pituitary hormones: LH (NIH-LH-B8), FSH (CH-1-76 potency $164 \times$ NIH-FSH-B1), TSH (30 i.u./mg, Pierce) and GH (NIH-GH-B15). It has been established previously that no serum interference occurred in the prolactin radioimmunoassay (McNeilly \& Land, 1979). Dilution curves of plasma from cows were parallel to the bovine prolactin standard and recovery (mean \pm s.e.m.) of added hormone to plasma was $97 \pm 3 \%(n=30)$. All the follicular fluid samples were assayed in one assay for each gonadotrophin and the intra-assay coefficient of variation was $\leqslant 6 \%$ in each instance. The detection limits of the assays were 0.16 $\mathrm{ng} \mathrm{LH} / \mathrm{ml}, 16 \mathrm{ng} \mathrm{FSH} / \mathrm{ml}$ and $0.5 \mathrm{ng}$ prolactin $/ \mathrm{ml}$. Results are expressed in terms of NIH-LH-B8, NIH-FSH-B1 and NIH-P-B 12 for LH, FSH and prolactin respectively.

Steroids. Concentrations of steroids in follicular fluid were determined using specific assays utilizing antisera and methods described previously for progesterone (Neal, Baker, McNatty \& Scaramuzzi, 1975), oestradiol-17ß (Van Look, Hunter, Corker \& Baird, 1977), testosterone (Corker \& Davidson, 1978) and androstenedione (Baird, Burger, Heavon-Jones \& Scaramuzzi, 1974). Steroids were extracted from follicular fluid before assay with petroleum ether (progesterone), diethyl ether (oestradiol-17 $\beta$ and androstenedione) or hexane : diethyl ether $(4: 1$ $\mathrm{v} / \mathrm{v}$ ) (testosterone). Recovery of steroids from follicular fluid was monitored by the addition of trace amounts of tritiated steroid $(\sim 1500$ c.p.m.) to the samples before their extraction. The mean procedural recoveries from fluid were: progesterone $72 \%$, oestradiol- $17 \beta 85 \%$, androstenedione $81 \%$ and testosterone $73 \%$. Steroids showing $>1 \%$ cross-reactivity with the antisera used were: 11 $\alpha$-hydroxyprogesterone $(35 \%)$; $11 \beta$-hydroxyprogesterone $(12 \%)$; $5 \alpha$ pregnane-3,20-dione $(17 \%)$; and 17-hydroxyprogesterone $(1.2 \%)$ with the progesterone antiserum; oestrone (5\%) and oestradiol-17 $\alpha$ (2\%) with the oestradiol-17 $\beta$ antiserum; $5 \alpha$-dihydrotestosterone $(24 \%)$ with the testosterone antiserum; $11 \beta$-hydroxyandrostenedione $(36 \%)$ and androsterone $(43 \%)$ with the androstenedione antiserum. The limits of sensitivity of the assays were: $1.5 \mathrm{ng}$ progesterone $/ \mathrm{ml}, 0.2 \mathrm{ng}$ oestradiol $-17 \beta / \mathrm{ml}$ and $0.5 \mathrm{ng}$ testosterone $/ \mathrm{ml}$ and $0.5 \mathrm{ng}$ androstenedione $/ \mathrm{ml}$. The intra- and inter-assay coefficients of variation were each $<10 \%$ and $<16 \%$ respectively for all of the assays. 


\section{Statistics}

Non-parametric statistics were used to avoid making assumptions about the distribution of the values in the populations from which the sample data were drawn. Accordingly, sample medians are given together with $95 \%$ confidence limits calculated as described by Campbell (1967) using Nair's table. Unless otherwise stated, significant differences were determined using the Kruskal-Wallis test (Hollander \& Wolfe, 1973) and comparisons of rank sums as described by Dunn (1964).

\section{Results}

Gonadotrophin concentrations in follicular fluid in relation to follicle size

Table 1 shows that, as follicle size increased, FSH concentrations in follicular fluid remained unchanged, LH concentrations declined significantly and prolactin concentrations increased significantly.

Table 1. Concentration of gonadotrophins $(\mathrm{ng} / \mathrm{ml})$ in bovine follicular fluid in relation to follicle size

\begin{tabular}{lccc}
\hline & \multicolumn{3}{c}{$\begin{array}{c}\text { Follicular size } \\
\text { (ml antral fluid/follicle) }\end{array}$} \\
\cline { 2 - 4 } & Small & Medium & Large \\
& $(<0 \cdot 3)$ & $(\geqslant 0 \cdot 3$ to $<0 \cdot 8)$ & $(\geqslant 0 \cdot 8)$ \\
& $*(36,42,41)$ & $*(28,33,33)$ & $*(36,36,37)$ \\
\hline FSH & $70^{\mathrm{a}}$ & $71^{\mathrm{a}}$ & $65^{\mathrm{a}}$ \\
& $(60-90)$ & $(62-82)$ & $(60-74)$ \\
LH & $4 \cdot 5^{\mathrm{a}}$ & $3 \cdot 7^{\mathrm{b}}$ & $3 \cdot 3^{\mathrm{bc}}$ \\
& $(4 \cdot 2-4 \cdot 7)$ & $(3 \cdot 4-4 \cdot 0)$ & $(3 \cdot 0-3 \cdot 5)$ \\
& $14^{\mathrm{a}}$ & $22^{\mathrm{ac}}$ & $30^{\mathrm{c}}$ \\
& $(10-17)$ & $(17-27)$ & $(24-45)$ \\
\hline
\end{tabular}

\footnotetext{
* No. of samples assayed for FSH, LH and prolactin respectively.

Values are medians with $95 \%$ confidence limits in parentheses.

Values with different superscripts in the same row are significantly different: ab $P<0.05 ;{ }^{\text {ac }} P<0.01$.
}

\section{Steroid concentrations in follicular fluid in relation to follicle size}

Table 2 shows that, as follicle size increased, follicular fluid concentrations of oestradiol-17 $\beta$ rose significantly, testosterone and androstenedione concentrations fell significantly and progesterone concentrations remained unchanged. The range of concentrations of steroids in follicular fluid within each follicle size class was very large. Oestradiol-17 $\beta$ concentrations $(\mathrm{ng} / \mathrm{ml})$ ranged from $<0.2$ to 65 in small follicles, from $<0.2$ to 890 in medium follicles and from $<0.2$ to 920 in large follicles. Testosterone and androstenedione concentrations $(\mathrm{ng} / \mathrm{ml})$ ranged from 1.6 to 138 and 2.0 to 166 respectively in small follicles, 0.5 to 240 and $<0.5$ to 313 respectively in medium follicles and 0.7 to 121 and $<0.5$ to 760 respectively in large follicles. Progesterone concentrations $(\mathrm{ng} / \mathrm{ml})$ ranged from 7 to 115 in small follicles, 10 to 164 in medium follicles and 10 to 390 in large follicles. 
Table 2. Concentration of steroids $(\mathrm{ng} / \mathrm{ml})$ in bovine follicular fluid in relation to follicle size

\begin{tabular}{lccc}
\hline & \multicolumn{3}{c}{$\begin{array}{c}\text { Follicle size } \\
\text { (ml antral fluid/follicle) }\end{array}$} \\
\cline { 2 - 4 } & Small & Medium & Large \\
& $(<0 \cdot 3)$ & $(\geqslant 0 \cdot 3$ to $<0 \cdot 8)$ & $(\geqslant 0 \cdot 8)$ \\
& $*(46)$ & $(35)$ & $*(36,37,35,34)$ \\
\hline Oestradiol-17 $\beta$ & $5^{\mathrm{a}}$ & $23^{\mathrm{c}}$ & $69^{\mathrm{c}}$ \\
Androstenedione & $(1-8)$ & $(15-97)$ & $\left(37^{\mathrm{c}}-142\right)$ \\
Testosterone & $32^{\mathrm{a}}$ & $18^{\mathrm{ab}}$ & $10^{\mathrm{b}}$ \\
& $(25-41)$ & $(6-30)$ & $(5-15)$ \\
Progesterone & $30^{\mathrm{a}}$ & $5^{\mathrm{c}}$ & $3^{\mathrm{c}}$ \\
& $(19-49)$ & $(2-14)$ & $(2-6)$ \\
& $35^{\mathrm{a}}$ & $37^{\mathrm{a}}$ & $39^{\mathrm{a}}$ \\
& $(24-53)$ & $(21-49)$ & $(25-58)$ \\
\hline
\end{tabular}

* No. of samples assayed for oestradiol-17 $\beta$, androstenedione, testosterone and progesterone respectively.

Values are medians with $95 \%$ confidence limits in parentheses.

Values with different superscripts in the same row are significantly different: ${ }^{\text {ab }} P<0.05 ;{ }^{\text {ac }} P<0.01$.

Relationship between follicle size and the ratio of oestradiol-17 $\beta$ to androgen concentrations in follicular fluid

As follicle size increased, there was a significant increase $(P<0.001$; contingency table analysis) in the proportion of follicular fluids in which the concentration of oestradiol-17 $\beta$ (E) in follicular fluid exceeded that of androgen (androstenedione + testosterone; $A+T$ ). The proportion of fluids with an E: $\mathrm{A}+\mathrm{T}$ ratio $>1$ was $3 / 46$ for small follicles $(1 / 31$ for the pools of fluid and $2 / 15$ for the fluids from individual follicles), $18 / 35$ for fluids from medium sized follicles and $30 / 36$ for large follicles.

\section{Relationship between FSH, oestradiol-17 $\beta$ and androgen concentrations in follicular fluid}

Table 3 shows that the relative concentrations of oestradiol-17 $\beta$ and androgen (testosterone + androstenedione) in follicular fluid were not related to those of FSH $(P>0.05$; Kruskal-Wallis).

Table 3. Relationship between bovine follicular fluid concentrations of FSH $(\mathrm{ng} / \mathrm{ml})$ and the ratio of fluid concentrations of oestradiol-17 $\beta$ and androgen (androstenedione + testosterone)

\begin{tabular}{lccccc}
\hline \multicolumn{5}{c}{ Ratio of oestradiol-17ß to androgen } \\
\cline { 2 - 5 } & $<10^{-2}$ & $\geqslant 10^{-2}$ to $<10^{-1}$ & $\geqslant 10^{-1}$ to $<10^{\circ}$ & $\geqslant 10^{\circ}$ to $<10$ & $\geqslant 10$ \\
\hline No. of samples & 8 & 24 & 20 & 33 & 15 \\
FSH & 81 & 66 & 71 & 64 & 68 \\
& $(52-185)$ & $(56-90)$ & $(60-96)$ & $(60-74)$ & $(60-100)$ \\
\hline
\end{tabular}

Values are medians with $95 \%$ confidence limits of the median in parentheses. 


\section{Relationship between prolactin and progesterone concentrations in follicular fluid}

There was a significant relationship between progesterone and prolactin concentrations in follicular fluid (Table 4): $70 \%$ of fluids examined had prolactin concentrations of $\leqslant 30 \mathrm{ng} / \mathrm{ml}$ and progesterone concentrations in these fluids ranged from 7 to $390 \mathrm{ng} / \mathrm{ml}$, although only $20 \%$ of these fluids had progesterone concentrations $>80 \mathrm{ng} / \mathrm{ml}$. As prolactin concentrations increased above $30 \mathrm{ng} / \mathrm{ml}$ there was a significant progressive decrease in the proportion of follicular fluids with progesterone concentrations $>35 \mathrm{ng} / \mathrm{ml}(P<0.02$, contingency table analysis).

Table 4. Contingency table showing the distribution of 106 follicular fluid samples with respect to follicular fluid prolactin and progesterone concentrations

\begin{tabular}{cccc}
\hline & \multicolumn{3}{c}{$\begin{array}{c}\text { Follicular fluid progesterone conc. } \\
\text { (ng/ml) }\end{array}$} \\
\cline { 2 - 4 } $\begin{array}{c}\text { Follicular fluid } \\
\text { prolactin conc. }(\mathrm{ng} / \mathrm{ml})\end{array}$ & $\leqslant 35$ & $>35$ to $\leqslant 80$ & $>80$ \\
\hline$\leqslant 30$ & 30 & 30 & 15 \\
$>30$ to $\leqslant 65$ & 12 & 10 & 0 \\
$>65$ & 8 & 1 & 0 \\
\hline
\end{tabular}

There was a significant relationship between follicular fluid concentrations of prolactin and those of progesterone $(P<0.02$; contingency table analysis).

\section{Discussion}

The interpretation of the results of the present study in terms of possible physiological events is limited by the fact that the ovaries were obtained from animals passing through an abattoir. Consequently, no information was available on the reproductive history of the animals or of the stage of their oestrous cycle at the time of slaughter. Nevertheless, the data do demonstrate that there were significant relationships between follicle size and the relative concentrations of gonadotrophins and steroids in bovine follicular fluid.

As follicle size increased, the steroid environment of follicular fluid changed from being predominantly androgenic to predominantly oestrogenic. In only $7 \%$ of small follicles examined was the oestradiol- $17 \beta$ concentration in follicular fluid greater than that of the androgens while in large follicles this figure was $83 \%$. In the cow, granulosa cells are the principal site of follicular androgen aromatization with oestradiol-17 $\beta$ being the major product (Lacroix, Eechaute \& Leusen, 1974). An increase in granulosa cell numbers and/or aromatase activity could account for the fall in fluid concentrations of androgen and rise of oestradiol-17 $\beta$ concentration associated with increasing follicle size (Table 2). The sharper fall in testosterone concentrations than in those of androstenedione is consistent with previous findings that bovine granulosa cells aromatize testosterone in preference to androstenedione (Henderson \& Swanston, 1978; Henderson \& Moon, 1979). FSH stimulates granulosa cell aromatase activity and in this way stimulates follicular oestradiol-17 $\beta$ production (Hillier, 1981). In women (McNatty, 1978) and sheep (McNatty et al., 1981) FSH concentrations in follicular fluid are related to the relative concentrations of oestradiol-17 $\beta$ and androgen present there-high FSH concentrations are associated with oestradiol-17 $\beta$ :androgen ratios $>1$ and low FSH concentrations to oestradiol-17 $\beta$ :androgen ratios of $<1$. No such relationship was evident in the present study (Table 3). Therefore, while FSH present in bovine follicular fluid may influence the aromatase activity of the follicle, it is unlikely to be the limiting factor regulating the aromatase activity 
expressed by the follicle, as reflected in the relative concentrations of oestradiol-17 $\beta$ and androgen in follicular fluid.

While there was no significant change in follicular fluid concentrations of FSH in relation to follicle size, fluid concentrations of $\mathrm{LH}$ and prolactin did change significantly (Table 1). $\mathrm{LH}$ concentrations fell slightly, but significantly, as follicle size increased. This may reflect some utilization of the fluid LH by follicular cells, particularly granulosa cells which are bathed in the follicular fluid. In contrast to $\mathrm{LH}$, prolactin concentrations in follicular fluid rose as follicle size increased, which is consistent with findings for sheep follicles (McNatty et al., 1981). Fluid concentrations of prolactin appeared to limit those of progesterone. Although there was no relationship between fluid progesterone concentrations and follicle size (Table 2), analysis of individual follicles revealed that high fluid progesterone concentrations $(>80 \mathrm{ng} / \mathrm{ml})$ only occurred when those of prolactin were low $\leqslant 30 \mathrm{ng} / \mathrm{ml}$ (Table 4). The high prolactin concentrations in follicular fluid could suppress granulosa cell progesterone production; prolactin inhibits progesterone production by human (McNatty, Sawers \& McNeilly, 1974) and procine (Veldhuis, Klase \& Hammond, 1980) granulosa cells in vitro.

While there were significant relationships between follicle size and the hormonal environment of follicular fluid, there was considerable variation, particularly in the steroid concentrations, between individual follicles of the same size. Thus, while one can generalize on how one population of follicles of a particular size is likely to differ from another, it is not possible to predict the follicular fluid environment of any individual follicle drawn from populations of follicles of defined size.

Bovine pituitary gonadotrophins were kindly supplied by the pituitary hormone distribution program of the NIAMDD, Bethesda, U.S.A. K.M.H. is presently in receipt of an Australian Queen Elizabeth II research fellowship.

\section{References}

Baird, D.T., Burger, P.E., Heavon-Jones, G.D. \& Scaramuzzi, R.J. (1974) The site of secretion of androstenedione in non-pregnant women. $J$. Endocr. 63, 201-212.

Bass, J.J., McNeilly, A.S. \& Moreton, H.E. (1979) Plasma concentrations of FSH and $\mathbf{L H}$ in entire and castrated prepubertal bull calves treated with $\mathrm{Gn}$ RH. J. Reprod. Fert. 57, 219-222.

Campbell, R.C. (1967) In Statistics for Biologists, p. 34. Cambridge University Press.

Corker, C. \& Davidson, D. (1978) A radioimmunoassay for testosterone in various biological fluids without chromatography. J. Steroid Biochem. 9. $373-374$.

Dunn, O.J. (1964) Multiple comparisons using rank sums. Technometrics 6, 241-252.

Henderson, K.M. \& Moon, Y.S. (1979) Luteinization of bovine granulosa cells and corpus luteum formation associated with loss of androgen aromatizing ability. J. Reprod. Fert. 56, 89-97.

Henderson, K.M. \& Swanston, I.A. (1978) Androgen aromatization by luteinized bovine granulosa cells in tissue culture. J. Reprod. Fert. 52. 131-134.

Hillier, S.G. (1981) Regulation of follicular oestrogen biosynthesis: a survey of current concepts. $J$. Endocr. 89, $3 P-18 P$.

Hollander, M. \& Wolfe, D.A. (1973) Nonparametric Statistical Methods, pp. 114-132. Wiley Publications, New York.
Ireland, J.J., Coulson, P.B. \& Murphree, R.L. (1979) Follicular development during four stages of the estrous cycle of beef cattle. J. Anim. Sci. 49, $1261-1269$.

Kanchev, L.N., Dobson, H., Ward, W.R. \& Fitzpatrick, R.J. (1976) Concentration of steroids in bovine peripheral plasma during the oestrous cycle and the effect of betamethasone treatment. J. Reprod. Fert. 48, 341-345.

Lacroix, E., Eechaute, W. \& Leusen, I. (1974) The biosynthesis of estrogens by cow follicles. Steroids 23, 337-356.

MeNatty, K.P. (1978) Cyclic changes in antral fluid hormone concentrations in humans. Clinics in Endocr. Metab. 7, 577-600.

McNatty, K.P., Sawers, R.S. \& McNeilly, A.S. (1974) A possible role for prolactin in control of steroid secretion by the human Graafian follicle. Nature, Lond. 250, 653-655.

McNatty, K.P., Gibb, M., Dobson, C., Thurley, D.C. \& Findlay, J.K. (1981) Changes in the concentration of gonadotrophic and steroidal hormones in the antral fluid of ovarian follicles throughout the oestrous cycle of the ewe. Aust.J. biol. Sci. 34, 67-80.

McNeilly, A.S. \& Andrews, P. (1974) Purification and characterization of caprine prolactin. $J$. Endocr. 60 , 359-367.

McNeilly, A.S. \& Land, R.B. (1979) Effect of suppression of plasma prolactin on ovulation, plasma 
gonadotrophins and corpus luteum function in LH-RH treated anoestrous ewes. J. Reprod. Fert. 57, 601-609.

McNeilly, J.R., McNeilly, A.S., Walton, J.S. \& Cunningham, F.J. (1976) Development and application of a heterologous radioimmunoassay for ovine follicle-stimulating hormone. J. Endocr. 70, 69-79.

Moor, R.M., Hay, M.F., Dott, H.M. \& Cran, D.G. (1978) Macroscopic identification and steroidogenic function of atretic follicles in sheep. J. Endocr. 77, 309-318.

Neal, P., Baker, T.G., McNatty, K.P. \& Scaramuzzi, R.J. (1975) Influence of progesterone and human chorionic gonadotrophin on progesterone concentrations and oocyte maturation in mouse ovarian follicles maintained in organ culture. J. Endocr. 65, 19-25.

Rahe, C.H., Owens, R.E., Fleeger, J.L., Newton, H.J. \& Harms, P.G. (1980) Pattern of plasma luteinizing hormone in the cyclic cow: dependence upon the period of the cycle. Endocrinology 107, 498-503.
Scaramuzzi, R.J., Caldwell, B.V. \& Moor, R.M. (1970) Radioimmunoassay of $\mathrm{LH}$ and estrogen during the estrous cycle of the ewe. Biol. Reprod. 3, 110-119.

Schams, D., Schallenberger, E., Hoffmann, B. \& Karg, H. (1977) The oestrous cycle of the cow: hormonal parameters and time relationships concerning oestrous, ovulation and electrical resistance of the vaginal mucus. Acta endocr., Copenh. 86, 180-192.

Van Look, P.F.A., Hunter, W.M., Corker, C.S. \& Baird, D.T. (1977) Failure of positive feedback in normal men and subjects with testicular feminization. Clin. Endocr. 7, 353-366.

Veldhuis, J.D., Klase, P. \& Hammond, J.M. (1980) Divergent effects of prolactin upon steroidogenesis by porcine granulosa cells in vitro: influence of cytodifferentiation. Endocrinology 107, 42-46.

Received 9 November 1981 